\title{
JAPAN, AMERICA AND DURABLE PEACE
}

\author{
By Toyoxichi Irenaga, Ph.D., \\ Professorial Lecturer in Political Science, University of Chicago; Director "East \\ and West News Bureau," New York.
}

The problems of a durable peace await, for their definite formulation and practical solution, the issue of the present war. If German militarism comes out victorious, peace dictated by it cannot be but temporary. If, on the other hand, the cause of justice and liberty be fully vindicated, the bitterest experiences and untold miseries the war has inflicted upon the world should teach the people thereof that the evil doctrine of "might over right" must forever be discarded, and some method devised to insure the stability of peace and safeguard the interest of humanity.

The world war, it seems to me, has already reached its last stage: a final decision cannot long be deferred. There was a time, I admit, when I entertained a doubt whether the European War would not end in a draw-in a peace without victory. When the policy and war measures adopted by the Entente Powers in the Balkans showed unmistakable signs of weakness, indecision and lack of cohesion, and in consequence the Allies were completely outmaneuvered and outfought in the vigorous well-managed campaigns prosecuted by the Central Powers, too much optimism regarding the decided triumph of the Allies' cause seemed unwarranted.

The first intimation that this temple of success reared by German arms could not long endure, but would sooner or later crumble to the ground by reason of the incompetence and blindness of German statesmanship, came to me through the publication of the now notorious Zimmermann note, which aimed to form a German-Japanese-Mexican Alliance to counteract the hostile measures of America. The monstrosity of that note was only equalled by its stupidity. As to Mexico, I am not in a position to know definitely her actual status or attitude; but for Japan I can assert most emphatically that the note is a sufficient warrant to judge how low German statesmanship has fallen, how utterly ignorant it is of Japan's history and aspirations. It completely ignores "the spirit of Japan," by whatever name described-the Yamato-Damashi or Bushido-which puts honor and loyalty foremost in the list of 
virtues. A nation that holds honor dear to its heart will never turn traitor to its allies or without cause attack another nation with which it is on friendly terms.

Germany doubtless measured Japan by her own standard of international ethics. Let me illustrate what I mean: Following the conclusion of the Shimonoseki Treaty, when Germany, Russia and France formed a formidable coalition with the purpose of robbing Japan of the best fruits of her victory over China by forcing upon her the retrocession of the Liaotung Peninsula, Prince Ito, then Premier of Japan, exclaimed:

Germany, we shall never forgive! Russia looks upon us as a future rival in the Far East; France is, of course, her ally, and has important possessions and ancient interests in Eastern Asia. We can understand their action. But for Germany, which always professed genuine friendship and has no special interests in those regions, to join hands with them and stab us in the back-her intervention was odious and gratuitous.

The reason why Germany joined the coalition was before long revealed to the world by the seizure of Kiaochow.

In the same treacherous manner, moved by the same unholy motive, Germany thought Japan may be induced to play her foul game and checkmate the United States in the event of war between the two powers! And what was the ground upon which Germany built her hope for success of the infamous intrigue? Recently the German foreign minister had the audacity to declare in effect before the Reichstag that Japan has less antagonism toward Germany, though at war with her, than she has toward the United States. True, the Japanese have no antagonism toward the German people; rather do we admire their many worthy qualities and the valuable contributions they have made to science, philosophy and literature. It would also be idle to deny that Japan has certair grievances against the United States, which it would be befitting to the great American people to redress in conformity to the principles of justice and "the square deal" they have proclaimed to the world. These grievances are, however, of local origin and are capable of amicable settlement. To the United States as a nation, Japan has always professed genuine friendship. And this profession is no make-believe; it is true, honest, sincere. Manifestly German statesmanship was well-nigh bankrupt when it hatched such a preposterous plot as the Zimmermann note reveals. 
And at last the death knell of German militarism was sounded when the American President and Congress resolved to enter the war! It is, indeed, beyond my comprehension how Germany could dare to challenge America to swell the ranks of her enemies. Have the great minds and statesmen who adorn the pages of German history left no heirs? Have the souls of Kant, of Goethe, of Bismarck, left the Fatherland as a condemnation of the horrible crimes Germans are today perpetrating on alien soils and the high seas? It was sheer madness for Germany to rouse the sleeping giant on this hemisphere and to let him mobilize the tremendous resources at his command in man power, money, credit and materials, for combatting the already hard-pressed foe. So far as the military situation in Europe goes, it may not be powerfully influenced, for a time, by the intervention of America, so that Germans can for a while dwell under the spell of their old illusion. But there is now no doubt as to which side of the belligerents will be final victor. When it is remembered that this war is so unlike other wars, that it is destined to be won on the farms, in the factories, the shipyards and the counting rooms, the overwhelming weight America brings will surely turn the scale to the side of the Allies.

The question that arises in our mind is, how long will be the time before Germany collapses? I make bold to say that it would be to the great advantage of Germany to sue for peace today and immediately stop this awful carnage and destruction before she has inflamed the American public by an hostile encounter. If she would now lay her cards upon the table and ask for lenient terms of settlement, her enemies would probably not be loath to grant them. In this respect the influence of America would doubtless be strongly exerted in Germany's favor. Were Germany so to act I could understand for the first time why she dragged the United States into this war.

The inertia of thought and action may, however, be too strong for Germany to take such a step before she has made another desperate move. The period of conflict then depends upon two contingencies - the result of submarine warfare and the decided stroke dealt by Germany upon Russia or separate peace with her. If both fail Germany is lost. We sincerely pray that the might of a newly born democracy of Russia will defeat the ambition of Germany. As to the submarine warfare, menacing as it is, the Allies will surely 
find a way to combat it. The god of the U-boat seems to have so enslaved the German mind that it cannot see that his frightfulness will now be fully matched by American inventiveness, and that many times more tonnage than he can destroy will be forthcoming from the all-embracing lap of the American giant. Surely the days of German militarism are numbered.

As one of the Entente Powers, Japan of course hails with joy the entrance of America into their ranks. There is, however, a special reason for Japan welcoming America, for there are between the two countries striking resemblances in the geographical positions they occupy and the attitudes they assume toward the European War. Effects of the war have hitherto been the same in both countries. The duties and functions America and Japan should fulfill are also similar-patrolling the neighboring seas, supplying their Allies with munitions and food and subscribing to their loans. I know not whether America will send an expeditionary force to Europe, but it is certain that neither America nor Japan would be interested in the remaking of the map of Europe. Both are waging war to crush German militarism, not the German people, so that an enduring peace based upon justice and liberty may be secured for the good of all nations. Consequently, in the future peace conference, America and Japan are more than likely to join hands in every move they make, and to exert their influence in unison. Such coöperation will doubtless serve, to quote the words of the Japanese Emperor in his congratulatory message to President Wilson, "to cement and consecrate the lasting friendship of our two nations."

In concluding, I may be permitted to add that, so far as America and Japan are concerned, nothing is more important for the furtherance of the cause of harmony than to eradicate the root of trouble that lies between the two countries. The task is not a difficult one, if you have only the will to do it. For the issue is simple and not at all in conflict with the vital interests of America. Japan is not playing the rôle of a pure idealist, clamorous for the immediate realization of ideas that, however lofty and equitable, disregard the existing condition of the world we live in-a world far unlike the "Kingdom of Heaven." Therefore, it should be definitely understood that Japan does not want to force upon the American people unrestricted immigration of her subjects. The "Gentlemen's Agreement" of 1907 stands intact and conforms to 
your wishes. What Japan asks is simply just and fair treatment to a small number of Japanese subjects residing in this country, in other words, the full recognition of their equality with people of other nationalities. Such recognition of equality, political and social, is denied to Japan, to speak frankly, so long as her subjects are discriminated against and cannot enjoy rights and privileges accorded to other aliens. It would be far from your thought, I hope, to begrudge Japan, now in the front rank of nations, full recognition of equality in America. Once this premise is granted, the logical conclusion that follows must be courageously faced, namely, that any discriminatory law or measure running counter to the principles of justice and fairness should be rectified or nullified. Pray do not misunderstand me. I am not insisting upon the repeal of the AntiAlien Land Act. I am simply advocating that the same principles of justice, equality and liberty, for whose defense you have not hesitated even to risk the hazard of this war, should be put into effect in the relation between America and Japan as in all international relations.

There may be many ways to accomplish the purpose. American resourcefulness, which is unbounded, is certainly equal to the task of finding the means. The trouble lies in the fact that the American people are not yet fully convinced of the vital importance of doing it. So long as this work remains undone, I must state with your permission what I consider to be the plain truth, much as I regret to say it, that the problems of a durable peace between America and Japan will not have received their definite and final solution. Consequently, while Japanese must do all in their power to make the work easy for you, at the same time I appeal to you most earnestly and sincerely to lend your powerful influence for the attainment of the object, so that the relations between our beloved countries may rest on the solid and safe rock of lasting friendship. 